\title{
Conceptual Framework of Innovation Strategy in SMEs
}

\author{
Nizar Alam Hamdani ${ }^{1}$, Sukma Nugraha ${ }^{1}$, Pupung Purnamasari ${ }^{2}$ \\ Universitas Garut ${ }^{1}$; STIE Pertiwi ${ }^{2}$ \\ Nizar_hamdani@uniga.ac.id
}

\begin{abstract}
The use of new innovations as tools to face competition is indeed considered effective enough to win the market. The absence of innovation will make consumers feel bored, leave the product, and we can be sure the business will sink amid the hustle and bustle of competition. This study analyzes the application of innovation strategy concepts in companies and SMEs. The approach in this study is scientific analysis of the literature and previous research on innovation strategies in SMEs. Based on the results of the study, the conceptual framework of the application of SME strategies was obtained, both dimensions, indicators and key to success and obstacles. The implication of this research is that there is an appropriate concept that can be used to develop research in the field of innovation strategy.
\end{abstract}

Keyword : innnovation, SMEs, strategy,

ABSTRAK: Penggunaan inovasi baru sebagai alat untuk menghadapi persaingan memang dianggap cukup efektif untuk memenangkan pasar. Tidak adanya inovasi akan membuat konsumen merasa bosan, meninggalkan produk, dan bisa dipastikan bisnis akan tenggelam di tengah hiruk pikuk persaingan. Studi ini menganalisis penerapan konsep strategi inovasi di perusahaan dan UKM. Pendekatan dalam penelitian ini adalah analisis ilmiah literatur dan penelitian sebelumnya tentang strategi inovasi di UKM. Berdasarkan hasil penelitian, kerangka kerja konseptual penerapan strategi SME diperoleh, baik dimensi, indikator dan kunci keberhasilan dan hambatan. Implikasi dari penelitian ini adalah bahwa ada konsep yang sesuai yang dapat digunakan untuk mengembangkan penelitian di bidang strategi inovasi.

Kata Kunci : inovasi, strategi, UKM

\section{INTRODUCTION}

SMEs play a considerable role in the economy in the Asia Pacific region. Data from the Asian Development Bank (ADB) shows that SMEs contribute up to 62 percent of employment and constitute 96 percent of the total number of companies in 20 countries in the Asia Pacific region. In addition, the contribution of SMEs to exports in various countries in the Asia Pacific region is fairly high: 40 percent in China and India, 26 percent in Thailand, 19 percent in South Korea, and 16 percent in Indonesia. In developed countries like Japan, SMEs contribute 70 percent of employment, 50 percent to GDP, and constitute 99 percent of the total number of companies in the country [1].

Previous studies have examined SME performance in terms of different aspects such as ICT use [2], intellectual capital approach [3], absorptive capability [4], distinctive capability [5], marketing strategy[6]-[8], electronic marketing[9]-[11], entrepreneurship [12], and entrepreneurial orientation [13].
SMEs business performance is largely determined by innovation because innovation enables SMEs to develop their businesses [14]. Innovation can also improve the competitiveness of SMEs [15];[16]. Financial performance, operating performance and company performance are also highly determined by and related to innovation [17].

Innovation strategy is an important issue to study because the innovation strategy is the key to successful SME performanc in various developing countries [18]. Innovation strategy is also worth studying due to the application of high technology in SMES to improve business performance [19]. This study examines conceptual innovation strategies that can be applied to SMEs to improve their performance and competitiveness.

\section{LITERATURE REVIEW}

Innovation as an economic success introduces new ways or new combinations of old ways of transforming inputs into outputs (technology) to 
produce a drastic change in the ratio between the perceived use value by consumers of the benefits of a product (goods and/or services) and the price set by producer [20]. Innovation is the process of turning opportunities into new ideas and putting them into practice. There are four types of innovation: (1) product innovation, which refers to changes in goods or services, (2) process innovation, which refers to changes in how a product is created or delivered, (3) position innovation, which refers to changes in how a product is introduced, and (4) Paradigm innovation, which refers to changes in mental models that underlie organizational activities [21].

Innovation as creation (discovery) focuses on using resources (manpower, time and fund) to create or develop new products, new services, new ways of doing things, and new ways of thinking [22]. Innovation as a product, process, and organizational change does not always originate from new scientific discoveries, but it can be a result of combining existing technologies and then applying them to new contexts. [23], [24]. Innovation is a deliberate change in the framework in which practical innovations extend to the point when demand is fully met. Today, the concept of innovation is quite open, transcends organizational boundaries, exploits not only internal changes but also external changes. It is also suggested that innovation is the fundamental basis of the competitiveness and a source of progress and development. Companies and nations that continue to innovate will succeed in sustaining their economic sustainability [25].

The basic thinking of the general strategy of innovation is to create a new product life cycle and thus make old similar products obsolete [26]. Innovation is different from creativity. Creativity is new thoughts; on the contrary, innovation is doing something new or transforming new ideas into a business success [27]. Innovation is the process of realizing these new ideas in the form of product innovation, service innovation, process innovation, and management innovation [26]. Innovation can be distinguished from the capacity for new ideas, which is the ability of organizations to develop or use new products and processes [28]. Innovation combined with several factors of competition culture can create a large capacity for new ideas, resulting in excellent organizational performance [29].

\section{METHODOLOGY}

The present study was conducted through a literature review. The literature included relevant books and scientific articles on innovation and innovation strategy. Facts and data were then analyzed using a descriptive approach.

\section{RESULT AND DISCUSSION}

Innovation strategies affects company performance. Balance scorecard approach shows that marketing, financial, business process performance are determined by an innovation strategy [30]. It is also suggested that innovation strategies are linked to formal structures, technological capabilities, and innovation performance [31], [32].

An innovation strategy plays an important role in determining the innovation capability of a company [33]. It has also a positive impact on the company's financial performance [34]. Innovation is a key to competitive advantage that determines the economic success of every organization [35]. It has been proven that there is a positive relationship between competitive advantage and technological innovation. Innovation in one area always affects other areas [29].

Innovation that systematically exploits changes is very effective. Innovation is a goal-directed search for changes that might offer for economic or social innovation [28]. When applied in SMEs, innovation strategy may be restricted by several factors as outlined in Table 1.

Table. 1 Barriers to Innovation in SMEs

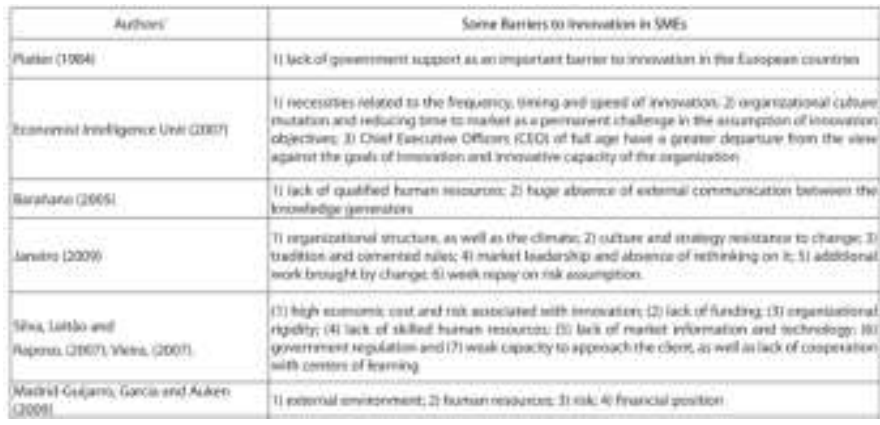

Source: [23]

Barriers to innovation in SMEs are generally linked to government policies, human resources, risks, 
weakness in predicting external environment, and limited financial capability.

Innovation strategy plays an important part in improving SMEs [19]. Studies suggest that innovation strategy in SMEs is closely related to their capability to adopt technology [36]. Dynamic conditions may enable SMEs make innovation to achieve the expected business performance [37].

Innovation strategy is related to the company's strategy response in adopting innovation. Previous studies have shown that there are many types of innovation strategy such as offensive innovation strategy, defensive innovation strategy, imitative innovation strategy, dependent innovation strategy, traditional innovation strategy, and opportunist innovation strategy [23], [38] (Freeman, 1978 in Hadjimanolis \& Dickson, 2000). This typology is based on the speed and time of entry of a company into the new technology area. Urban and Hauser (1980) in Hadjimonalis and Dickson (2000) distinguishes innovation strategy into proactive strategy and reactive strategy. The first is where a company projects and anticipates environmental changes. This strategy is usually employed by first mover companies. This strategy allows companies to build market share and reputation, but it requires high development costs and has the risk of investment in technology or faulty design. Reactive strategy is a strategy in which companies only react to consumer demand and competitors' activities[14].

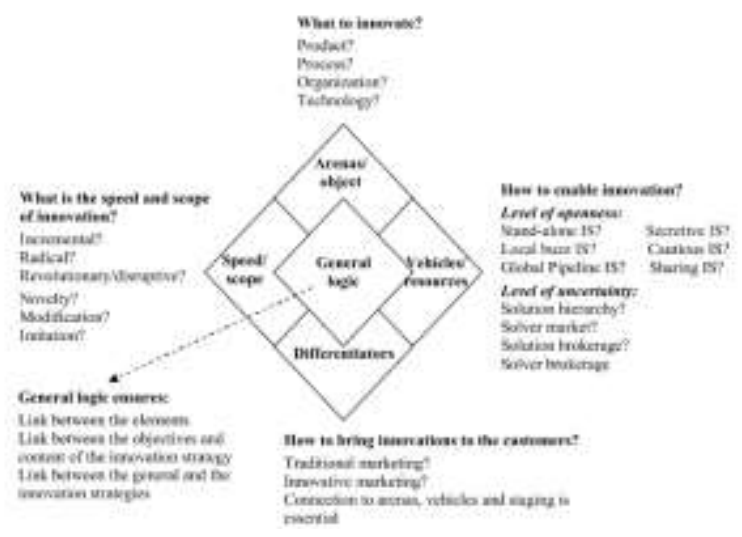

Figure 1 Fredickson's (2005) Model of Innovation Strategies

Source: [39]

Based on Fredickson's (2005) model, the appropriate innovation strategies to applied in SMEs are offensive, defensive, imitation (Jakubavicius, 2008), technological process, organizational process, and process innovation (Edquist Hommen and McKelvey, 2001).

\section{CONCLUSIONS}

The appropriate innovation strategies in SMEs are offensive, defensive, and imitation considering their internal and external factors including technology, process, and product. It is necessary for SMEs to be able to project and anticipate environmental changes.

\section{REFERENCES}

[1] Josephus and Primus, "Makin Besar, Peran UKM di Kawasan Asia Pasifik," Kompas.com, Jakarta, p. 1, May 2018.

[2] R. Ashrafi and M. Murtaza, "Use and Impact of ICT on SMEs in Oman.," Electron. J. Inf. Syst. Eval., vol. 11, no. 3, pp. 125-138, 2008, doi: ISSN 1566-6379.

[3] P. D. Astuti, "Hubungan Intellectual Capital dan Business Performance," J. Maksi, vol. 5, pp. 34-37, 2005.

[4] N. Tzokas, Y. A. Kim, H. Akbar, and H. AlDajani, "Absorptive capacity and performance: The role of customer relationship and technological capabilities in high-tech SMEs," Ind. Mark. Manag., vol. 47, pp. 134-142, 2015, doi: 10.1016/j.indmarman.2015.02.033.

[5] A. Rahim, A. Bakar, F. Hashim, and H. Ahmad, "Distinctive Capabilities and Strategic Thrusts of Malaysia ' $\mathrm{s}$ Institutions of Higher Learning," Int. J. Mark. Stud., vol. 1, no. 2, pp. 158-164, 2009.

[6] H. Keskin, "Market orientation, learning orientation, and innovation capabilities in SMEs: An extended model," Eur. J. Innov. Manag., vol. 9, no. 4, pp. 396-417, 2006, doi: 10.1108/14601060610707849.

[7] N. A. Hamdani and G. A. F. Maulani, "Analysis of Marketing of Sharia Banking Service Products Based on Consumer Perception," in lst International Conference on Islamic Economics, Business, and Philanthropy (ICIEBP 2017), 2017, pp. 515-520, doi: $10.5220 / 0007085005150520$.

[8] N. A. Hamdani, G. A. F. Maulani, Tetep, and D. Supriyadi, "Human Capital to competitive advantage of micro industry coffee in Garut Regency through distinctive," in Advances in Business, Management and Entrepreneurship, London: Taylor \& Francis Group, LLC, 2020, 
pp. 983-987.

[9] N. A. Hamdani, A. O. Herlianti, S. Nugraha, and A. Suparman, "Electronic - Word Of Mouth In Tourism 4 . 0 : Customer Review Of Online Travel Agent," no. 5, pp. 705-708, 2019, doi: 10.35940/ijeat.E1100.0585C19.

[10] S. Kim, B. Martinez, C. McClure, and S. H. Kim, "eWOM Intentions toward Social Media Messages," Atl. Mark. J., vol. 5, no. 1, pp. 137155, 2016.

[11] V. Kula and E. Tatoglu, "An exploratory study of Internet adoption by SMEs in an emerging market economy," Eur. Bus. Rev., vol. 15, no. 5, pp. 324-333, 2003, doi: 10.1108/09555340310493045.

[12] S. Effendi and D. Hadiwidjojo, "The Effect Of Entrepreneurship Orientation On The Small Business Performance With Government Role As The Moderator Variable And Managerial Competence As The Mediating Variable On The Small Business of Apparel Industry In Cipulir Market, South Jakarta," IOSR J. Bus. Manag., vol. 8, no. 1, pp. 49-55, 2013.

[13] R. Mahmood, "Entrepreneurial Orientation and Business Performance of Women-Owned Small and Medium Enterprises in Malaysia: Competitive Advantage as a Mediator," Int. J. Bus. Soc. Sci., vol. 4, no. 1, pp. 82-90, 2013.

[14] K. Ismail, W. Zaidi, W. Omar, K. Soehod, A. A. Senin, and C. S. Akhtar, "Role of Innovation in SMEs Performance: A Case of Malaysian SMEs," Math. Methods Eng. Econ. Role, vol. 1, no. 2, pp. 145-149, 2010.

[15] S. Moghavvemi, "Competitive Advantages Through It Innovation Adoption By Smes," vol. 7564, no. 1, pp. 24-39, 2012.

[16] M. R. Y. Zeebaree and R. Siron, "The Impact of Entrepreneurial Orientation on Competitive Advantage Moderated by Financing Support in SMEs," Int. Rev. Manag. Mark., vol. 7, no. 1, pp. 43-52, 2017.

[17] N. Kim-soon, A. R. Ahmad, C. W. Kiat, and H. R. Sapry, "SMES Are Embracing Innovation for Business Performance," J. Innov. Manag. Small Mediu. Enterp., vol. 1, pp. 1-17, 2017, doi: $10.5171 / 2017$.

[18] A. B. Susanto and Wasito, "Improve The Performance Of SMES Through Innovation Strategies In Developing Countries," Int. Jpurnal Sci. Technol. Reserach, vol. 6, no. 10, pp. 282-285, 2017.

[19] F. Sebiane, "The Contribution of Innovative
Strategy in The Growth of High Technology Smes and Their Business in Dubai," Int. J. Res. Manag. Bus. Stud. (IJRMBS 2016), vol. 3, no. 4, pp. 2014-2017, 2016.

[20] A. Fontana, Innovate We Can. Indonesia, 2011.

[21] J. Tidd and J. Bessant, Managing Innovation: Integrating Technological, Market and Organizational Change, 4th Editio. Great Britain: Wiley, 2009.

[22] C. D. Ahmed, Pervaiz K, \& Shepherd, Innovation Management, 1 Th Editi. New Jersey, USA: Pearson Education Inc, 2010.

[23] Ö. Ç. Bozkurt and A. Kalkan, "Business Strategies of SME' s, Innovation Types and Factors Influencing Their Innovation: Burdur Model," EGE Acad. Rev., vol. 14, no. 2, pp. 189-198, 2014.

[24] N. A. Hamdani and A. Ramdhani, Teori Organisasi. Garut: Karima, Bandung, 2019.

[25] A. Dibrov, "Innovation resistance: the main factors and ways to overcome them," Procedia - Soc. Behav. Sci., vol. 166, pp. 92-96, 2015, doi: 10.1016/j.sbspro.2014.12.489.

[26] M. Al-Battaineh, "Effect of Innovation Strategies on the Functional Performance of Smes Organizations in ( Hassan Industrial City )," Int. J. Bus. Manag. Invent., vol. 7, no. 5, pp. 12-18, 2018.

[27] E. Kabukcu, "Creativity process in innovation oriented entrepreneurship: The case of Vakko," Procedia - Soc. Behav. Sci., vol. 195, pp. 1321-1329, 2015, doi: 10.1016/j.sbspro.2015.06.307.

[28] Drucker and F. Peter, Innovation and Entrepreneurship, Practice and Principles. New York: Harper \& Row Publisher, 1985.

[29] C. Dibrell, P. Davis, and J. Craig, "Fuelling innovation through information technology in SMEs," J. small Bus. Manag., vol. 46, no. 2, pp. 203-218, 2008, doi: 10.1111/j.1540627X.2008.00240.x.

[30] A. T. Karabulut, "Effects of Innovation Types on Performance of Manufacturing Firms in Turkey," in World Conference on Technology, Innovation and Entrepreneurship, 2015, vol. 195, pp. 1355-1364, doi: 10.1016/j.sbspro.2015.06.322.

[31] R. Kamasak, "Determinants of innovation performance: a resource-based study," in World Conference on Technology, Innovation and Entrepreneurship, 2015, vol. 195, pp. 1330-1337, doi: 10.1016/j.sbspro.2015.06.311. 
[32] A. Hamdani, N.A dan Rhamdani, Manajemen Strategi, Edisi 1. Bandung: Karima, Bandung, 2019.

[33] C. A. Tushman, M., \& O'Reilly, Winning through innovation: A practical guide to leading organizational change and renewal, 6th Editio. Boston, USA: Harvard Business School Press., 1997.

[34] E. Nybakk and J. I. Jenssen, "Innovation strategy, working climate, and financial performance in traditional manufacturing firms: An empirical analysis," Int. J. Innov. Manag., vol. 16, no. April, pp. 1-30, 2012.

[35] M. Atalay, N. Anafarta, and F. Sarvan, "The relationship between innovation and firm performance: An empirical evidence from Turkish automotive supplier industry," in 2nd International Conference on Leadership, Technology and Innovation Management The, 2013, vol. 75, pp. 226-235, doi: 10.1016/j.sbspro.2013.04.026.

[36] N. Akmal, A. Wahab, and J. Jabar, "Organizational Innovation Strategy Towards Small Medium Enterprise Performance in Malaysia," Int. J. Arts Humanit. Soc. Sci., vol. 2, no. 7, pp. 1-9, 2017.

[37] Y. Wook and S. Wook, "Market dynamics and innovation management on Performance in SMEs : Multi-agent simulation approach," Procedia - Procedia Comput. Sci., vol. 91, no. Itqm, pp. 707-714, 2016, doi: 10.1016/j.procs.2016.07.060.

[38] C. López-Nicolás and Á. L. Meroño-Cerdán, "Strategic knowledge management, innovation and performance," Int. J. Inf. Manage., vol. 31, no. 6, pp. 502-509, 2011, doi: 10.1016/j.ijinfomgt.2011.02.003.

[39] I. Stankevice and G. Jucevicius, "Innovation Strategy : an Integrated Theoretical Framework Innovation Strategy : an Integrated Theoretical Framework," Soc. Moksl., vol. 69, no. 3, pp. 23-31, 2016. 